\title{
PENGARUH KARAKTERISTIK INDIVIDU DAN ORGANISASI TERHADAP KEMAMPUAN MANAJERIAL KEPALA MADRASAH TSANAWIYAH NEGERI SE KOTA MATARAM
}

\author{
Marlia Zuhro, Aos Santoso Hadiwijaya, M.Zulfikar Syuaib, \\ Program Pascasarjana Universitas Mataram. \\ marliamtsn@gmail.com,aos_santoso@yahoo.com,phi_car@unram.ac.id
}

\begin{abstract}
ABSTRAK:Penelitian ini bertujuan untuk mengetahui pengaruh secara simultan dan parsial karaktristik individu dan karakteristik organisasi terhadap kemampuan manajerial kepala madrasah. Jenis penelitian yang digunakan adalah penelitiansurvei, dengan populasi 102 orang terdiri dari staf dan guru PNS pada madrasah tsanawiyah negeri 1, 2 dan 3 Mataram. Penentuan jumlah sampel menggunakan rumus persamaan slovin dan pengambilan sampel secara simple random sampling sebanyak 50 orang. Teknik pengambilan data menggunakan angket, dan dianalisis menggunakan aplikasi program statistik . Berdasarkan hasil uji menunjukkan terdapat pengaruh variabel karakteristik individu dan karakteristik organisasi secara simultan terhadap kemampuan manajerial kepala madrasah tsanawiayah negeri se Kota Mataram, dengan koefisien determinasi atau R Square sebesar 0,634 atau 63,4\%. Hasil uji secara parsial karakteristik individu terhadap kemampuan manajerial kepala madrasah tsanawiyah negeri se Kota Mataram diperoleh nilai koefisien determinasi sebesar 0,373 atau 37,3\%. Hal ini menunjukan bahwa karakteristik individu dapat memberikan pengaruh terhadap kemampuan manajerial kepala madrasah sebesar 37,3\%, sedangkan sisanya 62,7\% dipengaruhi variabel yang tidak diteliti. Sedangkan pengaruh organisasi terhadap kemampuan manajerial kepala madrasah dengan nilai koefisien determinasi atau $\mathrm{R}$ Square sebesar 0,612 atau 61,2\%. Hal ini menunjukan bahwa variabel yang diteliti karakteristik organisasi dapat memberikan pengaruh terhadap kemampuan manajerial kepala madrasah sebesar 61,2\%.

Kata kunci : Karakteristik individu, karakteristik organisasi, kemampuan manajerial kepala madrsah
\end{abstract}

ABSTRACT : This study aims to determine the simultaneous and partial effect of individual characteristics and organizational characteristics towards the managerial ability of the principle of madrasah. The type of research is survey, with 102 people of population consisted of labor system and government employeer teachers at MTsN 1,2,3Mataram. The sample determined by slovin formula and were collected by simple random sampling is 50 people. The data were collected by quesionaire and analayzed using the statistic program application. Based on the result, indicated that there were simultaneous effect of individual characteristics and organizational characteristics toward the managerial ability of the principle of madrasah, with coefficient determination is 0,373 Or 37,3\%. This result indicated that individual characteristics influenced toward the managerial ability is 37,3\% while the balance is $62,7 \%$ were influenced by the other variable. The effect of organizational characteristics toward the managerial ability of the principle of madrasah with coefficient determination is 0,612 or 61,2 $\%$. It means the organizational characteristic influenced towards the managerial ability of principal of madrasah is $61,2 \%$.

Keywords : individual characteristic, organization characteristic, principle managerial ability 


\section{PENDAHULUAN}

Madrasah adalah satuan pendidikan formal dalam binaan Menteri Agama yang menyelenggarakan pendidikan umum dan kejuruan dengan kekhasan agama islam yang mencakup Raudhatulul Athfal (RA), Madrasah Ibtidaiyah (MI), Madrasah Tsnawiyah (MTs) Madrasah Aliyah (MA) dan Madrasah Aliyah Khusus (MAK) yang mempunyai tugas, fungsi, wewenang dan tanggung jawab sesuai dengan PMA Nomor 29 Tahun 2014 yang di dalamnya terdapat kepala madrasah, wakil kepala madrasah, guru-guru, pegawai tata usaha, supervisor dan siswa-siswa.

Kepala madrasah adalah pimpinan yang tertinggi di madrasah. Kepala madrasah memegang peranan penting dalam menentukan segala sesuatunya baik yang berhubungan dengan tugas madrasah ke dalam maupun ke luar. Dalam struktur organisasi madrasah, kepala madrasah adalah guru yang diberikan tugas tambahan untuk membina dan memimpin anggotanya dengan ketentuan jabatan kepala madrasah telah ditetapkan berdasarkan Peraturan Menteri Pendidikan Nasional Nomor 13 Tahun 2007 tentang Standar Kepala Sekolah, dan Peraturan Menteri Agama Nomor 29 Tahun 2014. Di samping persyaratan di atas seorang kepala madrasah juga harus memiliki kompetensi yaitu kepribadian, manajerial, kewirausahaan, supervisi dan sosial

Kemampuan manajerial kepala madrasah mempunyai peranan yang sangat besar karena kepala madrasah merupakan motor penggerak, penentu arah kebijakan madrasah. Sebagai pengelola instansi satuan pendidikan, kepala madrasah dituntut untuk selalu meningkatkan efektivitas kinerjanya, untuk mencapai mutu madrasah yang efektif, kepala madrasah dan seluruh yang terlibat di dalamnya harus bahu membahu dan bekerja sama dengan penuh kekompakan dalam segala hal. Kepala madrasah yang efektif adalah kepala madrasah yang dalam kinerjanya selalu membuka diri dalam menerima masukan dari guru dan karyawan lainnya dalam berbagai persoalan.

Hasil observasi menunjukkan bahwa sistem promosi kepala madrasah masih berdasarkan Daftar Urutan Kepangkatan (DUK) dan pernah menjabat sebagai wakil kepala madrasah, maka dapat diangkat menduduki jabatan sebagai kepala madrasah. Pengangkatan kepala madrasah dilakukan tanpa melalui rekrutmen, seleksi dan assesmen kompetensi kepribadian, kompetensi manajerial, kompetensi kewirausahaan, kompetensi supervisi dan kompetensi sosial, serta tidak berpedoman dengan PMA mengakibatkan kepala madrasah kurang memiliki keahlian manajerial sehingga tidak tercapainya tujuan madrasah.

Pengangkatan kepala madrasah harus berpedoman pada aturan yang telah ditetapakan berdasarkan Peraturan Menteri Agama Nomor 29 Tahun 2014 BAB IV Pasal 8 yang menyebutkan bahwa salah syarat menjadi kepala madrasah memiliki Surat Tanda Tamat Pendidikan dan Pelatihan (STTPL) kepala madrasah yang diterbitkan oleh Kementerian Agama.

Pengangkatan kepala madrasah harus didasarkan pada seleksi dan assesmen kompetensi untuk mendapatkan kepala madrasah yang memiliki kemampuan manajerial yang ditetapkan Peraturan Menteri Agama Nomor 19 Tahun 2014 sehingga 
tujuan pendidikan madrasah akan tercapai secara optimal.

Adapun tujuan penelitian ini adalah:1). Untuk mengetahui apakah karakteristik individu dan organisasi berpengaruh terhadap kemampuan manajerial kepala madrasah tsanawiyah negeri se Kota Mataram, 2). Untuk mengetahui apakah karakteristik individu berpengaruh terhadap kemampuan manajerial kepala madrasah tsanawiyah negeri se Kota Mataram, 3). Untuk mengetahui apakah karakteristik organisasi berpengaruh terhadap kemampuan manajerial kepala madrasah tsanawiyah negeri se Kota Mataram

Seorang kepala madrasah sebagai manajerial dituntut mampu memiliki kesiapan dalam mengelola madrasah. Kesiapan yang dimaksud adalah berkenaan dengan kemampuan manajerial kepala madrasah sebagai seorang pimpinan. Kemampuan manajerial yang dimaksudkan di sini adalah berkenaan dengan kemampuannya dalam membuat perencanaan (planning), mengorganisasikan (organizing), pelaksanaan (actuating), dan pengawasan (controlling). Dengan kemampuan semacam itu, diharapkan setiap pimpinan mampu menjadi pendorong dan penegak disiplin bagi para karyawannya agar mereka mampu menunjukkan produktivitas kerjanya dengan baik. (Said, 2013: 61)

Menurut Marno, dkk. (2013:13) Perencanaan (planning) merupakan keseluruhan proses pemikiran dan penentuan secara matang tentang hal-hal yang akan dikerjakan di masa yang akan datang dalam rangka mencapai tujuan yang telah ditentukan. Perencanaan ini dirumuskan dan ditetapkan seluruh aktivitas lembaga yang menyangkut apa yang harus dikerjakan, mengapa dikerjakan, di mana dikerjakan, kapan akan dikerjakan, siapa yang mengerjakan dan bagaimana hal tersebut dikerjakan.

Pengorganisasian (organizing) merupakan lanjutan dari fungsi perencanaan dalam sebuah sistem manajemen. Pengorganisasian bisa dikatakan urat nadi bagi seluruh organisasi dan lembaga. Oleh karena itu, pengorganisasian sangat berpengaruh terhadap berlangsungnya suatu organisasi.

Menurut Kurniadin, dkk. (2012:129) pengorganisasian adalah kegiatan untuk mencapai tujuan yang dilakukan oleh sekelompok orang, dilakukan dengan membagi tugas, tanggung jawab, dan wewenang diantara mereka, ditentukan siapa yang menjadi pemimpin, serta saling berintegrasi secara aktif.

Penggerakan (actuating), adalah aktivitas untuk memberikan dorongan, pengarahan, dan pengaruh terhadap semua anggota kelompok agar mau bekerja secara sadar dan suka rela dalam rangka mencapai suatu tujuan yang ditetapkan sesuai dengan perencanaan dan pola organisasi (Said, 2010:285). Masalah penggerakan ini pada dasarnya berkaitan erat dengan unsur manusia sehingga keberhasilannya juga ditentukan oleh kemampuan kepala madrasah dalam berhubungan dengan para guru dan karyawannya. Oleh sebab itu, diperlukan kemampuan kepala madrasah dalam berkomunikasi, daya kreasi serta inisiatif yang tinggi dan mampu mendorong semangat dari para guru dan karyawannya.

Pengawasan (controlling), dapat diartikan sebagai salah satu kegiatan untuk 
mengetahui realisasi perilaku personel dalam organisasi pendidikan dan apakah tingkat pencapaian tujuan pendidikan sesuai dengan yang dikehendaki, kemudian apakah perlu diadakan perbaikan. Pengawasan dilakukan untuk mengumpulkan data tentang penyelenggaraan kerja sama antara guru, kepala madrasah, konselor, supervisor, dan petugas madrasah lainnya dalam institusi satuan pendidikan (Said, 2010:285)

Karakteristik individu adalahciri tertentu dari individu untuk dibedakan satu dengan yang lainnya, baik dalam sikap maupun prilaku berdasarkan indikator pendidikan merupakan faktor penting dalam menentukan kemampuan kerja seseorang, keahlian yang diperlukan seserang di dalam memimpin organisasi dan pengalaman kerja yang menunjukkan banyaknya jenis pekerjaan atau jabatan yang pernah diduduki oleh seseorang. Karakteristik individu membawa kedalam tatanan organisasi dan dapat mempengaruhi kemampuan manajerial kepala madrasah.

Organisasi merupakan wadah bagi individu untuk mencapai tujuan, baik tujuan pribadi maupun tujuan organisasi. Karakteristik individu membawa ke dalam tatanan organisasi, kemampuan, kepercayaan, pribadi, kebutuhan, penghargaan dan pengalaman masa lalunya. Ini semua adalah karakteristik yang dimiliki individu dan karakteristik ini akan memasuki suatu lingkungan baru, yakni organisasi (Thoha, 1993:30). Sejalan dengan hal tersebut Robbins (2002:52) mengungkapkan beberapa karakteristik pribadi yang meliputi umur, jenis kelamin, status perkawinan, banyaknya tanggung jawab dan status masa kerja. Karakteristik individu dilihat dari keahlian, pendidikan dan pengalaman kerja, (Hasibuan, 2000:55)

Kepala madrasah sebagai seorang pemimpin mampu mengarahkan segenap sumber daya yang ada untuk mencapai tujuan organisasi, sumber daya madrasah yang dikelola meliputi visi, misi, program, tujuan atau sasaran pendidikan, kurikulum, media pembelajaran, peserta didik, tenaga pendidik dan kependidikan, sarana dan prasarana, pendanaan, orang tua peserta didik dan masyarakat lingkungan serta jaringan kerja sama dengan pihak luar dalam menjalankan serta mengembangkan tugas dan fungsinya kepala madrasah mampu menjalankan secara optimal.

\section{METODE PENELITIAN}

Penelitian ini dilaksakan di Kota Mataram bertempat di MTsN 1 Mataram, MTsN 2 Mataram, dan MTsN 3 Mataram dengan waktu penelitian pada bulan April s/d Juni tahun 2015. Jenis penelitian ini yang digunakan adalah penelitiansurvei.Survei merupakan cara pengumpulan data dari sejumlah unit atau individu dalam waktu atau kurun waktu bersamaan. Pengumpulan informasi dari responden yang terpilih dilaksanakan dengan kuisioner mempergunakan daftar pertanyaan yang telah disiapkan (Sudjarwo, dkk. 2009:128).

Survei dimaksudkan adalah survei dengan membatasi pada sampel di mana informasi dikumpulkan dari sebagian populasi. Survei dilakukan pada madrasah tsanawiyah negeri se Kota Mataram dengan data yang dikumpulkan dalam penelitian ini terdiri tiga variabel yang terdiri dari dua variabel bebas dan satu variabel terikat. Variabel bebas dalam penelitian ini adalah: 
Karakteristik individu yang meliputi keahlian, pendidikan dan pengalaman kerja, dan karakteristik organisasi yang meliputi sumber daya organisasi, iklim organisasi, dan struktur organisasi, sedangkan variabel terikat adalah kemampuan manajerial kepala madrasah tsanawiyah negeri se Kota Mataram

Populasi pada penelitian ini adalah wilayah generalisasi yang terdiri atas: objek/subjek yang mempunyai kualitas dan karakteristik tertentu yang ditetapkan oleh peneliti untuk dipelajari dan kemudian ditarik kesimpulannya (Arikunto 2013:173). Populasi dalam penelitian ini adalah jumlah keseluruhan Pegawai Negeri Sipil yaitu guru dan staf tata usaha pada madrasah tsanawiyah negeri se Kota Mataram sebanyak 102 orang, dalam penelitian ini teknik penarikan sampelnya adalah secara acak sederhana (simple random sampling), diperoleh sampel 50 orang.

Sebelummelakukan uji hipotesis, terlebih dahulu dilakukan uji asumsi klasik regresi ganda yaitu uji normalitas, uji heteroskedastisitas dan uji multikolinieritas. Uji hipotesis dalam peneliian ini diuji dengan analisis regresi ganda untuk mengetahui prediksi seberapa besar pengaruh dari variabel bebas secara simultan terhadap variabel terikat. Selain mengguanakan uji regresi ganda dilkukan juga analisis regresi sederhana untuk mengetahui prediksi seberapa besar pengaruh dari variabel bebas secara parsial terhadap variabel terikat.

\section{HASIL PENELITIAN DAN}

\section{PEMBAHASAN}

Hasil deskripsi jawaban responden atas variabel karakter individu yang menjawab sangat setuju 40,68\%; menjawab setuju 51,31\%; menjawab kurang setuju 7,24\%; menjawab tidak setuju $0,77 \%$ dan menjawab sangat tidak setuju tidak ada. Hasil ini menunjukkan bahwa paling banyak responden menjawab setuju $51,31 \%$, sedangkan yang paling sedikit responden menjawab sangat tidak setuju $0 \%$, berarti sebagian besar responden mempersepsikan positif mengenai variabel karakteristik individu. Hasil ini mengindikasikan bahwa variabel karakteristik individu yang ada pada MTsN se Kota Mataram di nilai baik oleh responden.

Hasil deskripsi jawaban responden atas variabel karakteristik organisasi yang menjawab sangat setuju 36,70\%; menjawab setuju 56,55\%; menjawab kurang setuju 4,00\%; menjawab tidak setuju 2,00\%; menjawab sangat tidak setuju 0,75\%. Hasil ini menunjukkan bahwa paling banyak responden menjawab setuju 56,55\%, sedangkan yang paling sedikit responden menjawab sangat tidak setuju $0,75 \%$, berarti sebagian besar responden mempersepsikan positif mengenai variabel karakteristik organisasi. Hasil ini mengindikasikan bahwa karakteristik organisasi yang ada pada MTsN se Kota Mataram dinilai baik oleh responden.

Hasil deskripsi jawaban responden atas variabel kemampuan manajerial kepala madrasah yang menjawab sangat setuju $32,27 \%$; menjawab setuju 52,21\%; menjawab kurang setuju 13,70\%; menjawab tidak setuju 1,36\%; sangat tidak setuju 0,46\%. Hasil ini menunjukkan bahwa paling banyak responden menjawab setuju $52,21 \%$, sedangkan yang paling sedikit 
responden menjawab sangat tidak setuju $0,46 \%$, berarti sebagian besar responden mempersepsikan positif mengenai variabel kemampuan manajerial kepala madrasah. Hasil ini mengindikasikan bahwa variabel kemampuan manajerial kepala madrasah yang ada pada MTsN se Kota Mataram dinilai baik oleh responden.

\section{Pengujian hipotesis secara simultan : pengaruh karakteristik individu dan karakteristik organisasi terhadap kemampuan manajerial kepala madrasah}

Diperoleh persamaan regresi linier ganda sebagi berikut: Kemampuan manajerial $(\mathrm{Y})=0,915+0,231 \quad \mathrm{X} 1+0,505 \quad \mathrm{X} 2+\mathrm{e}$ dari persamaan regresi linier ganda di atas diperoleh nilai konstanta sebesar 0,915 artinya, apabila nilai karakteristik individu dan organisasi bernilai nol maka akan memberikan nilai kemampuan manajerial kepala madrasah sebesar 0,915.

Uji linearitas adalah pengujian yang bertujuan untuk mengetahui apakah regresi bersifat linier atau tidak menggunakan tabel ANOVA variabel $\mathrm{X}$ dan $\mathrm{Y}$ dari nilai signifikan tabel ANOVA $<0,05$ maka dapat disimpulkan bahwa hubungan bersifat linier menggunakan SPSS 17.0 dengan hasil pengujian sebagai berikut:

\begin{tabular}{|c|c|c|c|}
\hline Model & Df & $\mathbf{F}$ & Sig \\
\hline 1 Regresi & 2 & \multirow[t]{3}{*}{40,681} & \multirow[t]{3}{*}{0,000} \\
\hline Residual & 47 & & \\
\hline Total & 49 & & \\
\hline
\end{tabular}

Berdasarkan tabel dapat dilihat bahwa nilai signifikan tabel ANOVA sebesar 0,000 artinya nilai signifikan kurang dari 0,05 $(0,000<0,05)$ yang berarti bahwa hubungan bersifat linier. Hal ini menunjukkan bahwa karakteristik individu dan karakteristik organisasi berpola linier terhadap kemampuan manajerial kepala madrasah, sedangkan untuk mengetahui signifikan pengaruh variabel independen secara bersama-sama terhadap variabel dependen digunakan uji $\mathrm{F}$ diperoleh nilai F hitung sebesar 40,681 pada nilai $\mathrm{F}$ tabel pada tingkat signifikansi 5\% adalah sebesar 3,195 (interpolasi). Jika kedua nilai ini dibandingkan maka nilai $\mathrm{F}$ hitung lebih besar dari $\mathrm{F}$ tabel dengan hasil perbandingan 40,681 > 3,195 (F hitung $>\mathrm{F}$ tabel) dengan nilai signifikan $0,000 \leq 0,05$ sehingga Ho ditolak. Dengan demikian dapat disimpulkan bahwa secara simultan variabel karakteristik individu dan karakteristik organisasi memiliki pengaruh yang signifikan terhadap variabel kemampuan manajerial kepala madrasah.

Analisis korelasi digunakan untuk mengetahui hubungan variabel karakteristik individu dan karakteristik organisasi dengan kemampuan manajerial kepala madrasah.. Di peroleh hasil analisis korelasi antara variabel karakteristik individu dan karakteristik organisasi dengan variabel kemampuan manajerial kepala madrasah sebagai berikut: 


\begin{tabular}{|l|l|l|}
\hline Model & $\mathbf{R}$ & R square \\
\hline 1 & 0,796 & 0,634 \\
\hline
\end{tabular}

Berdasarkan output tersebut dapat diketahui koefisien korelasi (R) antara variabel independen dan dependen sebesar 0,796. Adapun nilai $\mathrm{R}$ tabel pada tingkat signifikansi 5\% adalah sebesar 0,279. Jika kedua nilai ini dibandingkan maka nilai $\mathrm{R}$ hitung lebih besar dari $\mathrm{R}$ tabel, dengan hasil perbandingan 0,796 $>0,279$ ( $\left.\mathrm{R}_{\text {hitung }}>\mathrm{R}_{\text {tabel }}\right)$. Hal ini menunjukkan terdapat hubungan antara karakteristik individu dan karakteristik organisasi dengan kemampuan manajerial kepala madrasah. Sedangkan hasil uji signifikansi diperoleh nilai $\mathrm{F}$ hitung 39,625 pada taraf signifikansi $5 \%$, diperoleh $\mathrm{F}$ tabel sebesar 3,195 Dengan hasil perbandingan $\mathrm{F}$ hitung $(39,625)>\mathrm{F}$ tabel $(3,195)$ maka Ho ditolak dan $\mathrm{Ha}$ diterima. Dengan demikian dapat disimpulkan bahwa terdapat hubungan yang signifikan antara variabel karakteristik individu dan karakteristik organisasi terhadap kemampuan manajerial kepala madrasah dengan nilai signifikansi $0,000<0,05$, maka karakteristik individu dan karakteristik organisasi berpengaruh positif dan signifikan terhadap kemampuan manajerial kepala madrasah tsanawiyah negeri se Kota Mataram, dengan besarnya koefisien diterminasi dilihat bahwa nilai koefisien determinasi atau R Square sebesar 0,634 atau $63,4 \%$. Hasil ini mengindikasikan bahwa secara bersama-sama karakteristik individu dan karakteristik organisasi dalam melaksanakan pekerjaan sesuai tugas pokok dan fungsi yang ada, dapat bekerjasama dengan baik, mampu memotivasi guru dan pegawai, memiliki kemampuan dalam menuangkan gagasan dalam melaksanakan pekerjaan, memiliki sumber daya organisasi yang ahli dalam membuat rencana kerja, mengelola dan membuat perencanaan dengan baik dan memiliki kemampuan dalam menyampaikan informasi dan ditunjang dengan kemampuan memfasilitasi pengembangan kemampuan dan keterampilan guru dan pegawai.

Iklim organisasi yang kondusif khususnya dalam kondisi lingkungan kerja yang dapat menunjang organisasi serta memberikan kesempatan kepada guru dan pegawai untuk mengembangkan diri serta pembagian kerja dilakukan dengan jelas, kewenangan dilakukan sesuai dengan tanggungjawab yang dimiliki guru dan pegawai, koordinasi dilakukan secara terintegrasi maka dapat menyebabkan meningkatnya kemampuan manajerial kepala madrasah.

Hasil penelitian ini selaras dengan penelitian Siswantoro (2009) yang menyatakan bahwa terdapat pengaruh antara karakteristik organisasi dan individu terhadap pengembangan karir guru dan pegawai pada kantor badan pengawas pasar modal dan lembaga keuangan departemen keuangan. Dan hasil penelitian Handayani (2010) menyatakan bahwa terdapat pengaruh antara karakteristik organisasi dan individu secara simultan terhadap pengembangan karir pejabat struktural pada kantor pemerintah provinsi NTB. Teori-teori terkait dengan pengaruh karakteristik individu, dan karakteristik organisasi terhadap kemampuan manajerial kepala madrasah, yang sesuai dengan hasil penelitian ini adalah menurut konsep Schein dalam Durbin Watson faktorfaktor yang mempengaruhi kemampuan manajerial kepala madrasah adalah 
manajerial competence (kemampuan manajerial), technical/fungsional competence (kemampuan teknis/fungsional), scurity (keamanan), creativity (kreativitas) dan autonomi and independence (otonomi dan kebebasan).

Simamora $(1997 ; 31)$ menyatakan bahwa sumber daya, iklim, tujuan dan struktur organisasi mempengaruhi kemampuan manajerial kepala madrasah yang akhirnya berdampak pada penerapan pelaksanaan fungsi manajemen, sejalan dengan hasil penelitian ini bahwa karakteristik organisasi yang meliputi sumber daya, iklim organisasi dan struktur organisasi berpengaruh terhadap kemampuan manajerial kepala madrasah tsanawiyah negeri se Kota Mataram.

\section{Pengujian hipotesis secara parsial : Pengaruh karakteristik individu terhadap kemampuan manajerial kepala madrasah}

Pengaruh karakteristik individu terhadap kemampuan manajerial kepala madrasah secara parsial dapat dilihat dengan menggunakan analisis regresi linier sederhana dengan persamaan sebagai berikut: Kemampuan manajerial $(\hat{\mathrm{Y}})=\beta_{0}+\beta_{1} \mathrm{X}_{1}+\mathrm{e}$. Hasil pengolahan analisis regresi sederhana sebagai berikut: Kemampuan manajerial $(\hat{Y})$ $=1,009+0,739 \mathrm{X} 1+\mathrm{e}$. Dari persamaan regresi linier sederhana di atas diperoleh nilai konstanta sebesar 1,009 artinya, apabila nilai karakteristik individu dan organisasi bernilai nol maka akan memberikan nilai kemampuan manajerial kepala madrasah sebesar 1,009.

Uji linearitas adalah pengujian yang bertujuan untuk mengetahui apakah regresi bersifat linier atau tidak. Uji linieritas dalam penelitian ini menggunakan tabel ANOVA variabel $X$ dan $Y$ dari nilai signifikan. Apabila nilai signifikan tabel ANOVA $<0,05$ maka dapat disimpulkan bahwa hubungan bersifat linier dengan hasil uji sebagai berikut:

\begin{tabular}{|ll|l|l|l|}
\hline \multicolumn{1}{|c|}{ Model } & Df & F & Sig \\
\cline { 1 - 2 } 1 & Regresi & 1 & 28,511 & 0,000 \\
\cline { 1 - 2 } Residual & 48 & & \\
\cline { 1 - 2 } Total & 49 & & \\
\hline
\end{tabular}

Berdasarkan tabel di atas dapat dilihat bahwa nilai signifikan tabel ANOVA sebesar 0,000. Artinya nilai signifikan kurang dari 0,05 $(0,000<0,05)$ yang berarti bahwa hubungan bersifat linier. Hal ini menunjukan bahwa karakteristik individu berpola linier terhadap kemampuan manajerial kepala madrasah. Sedangkan untuk mengetahui signifikan pengaruh variabel independen karakteristik individu secara parsial terhadap kemampuan manajerial kepala madrasah digunakan uji F. diperoleh nilai $F$ hitung sebesar 28,511 dengan nilai $F$ tabel pada tingkat signifikansi 5\% adalah sebesar 4,04. Jika kedua nilai ini dibandingkan maka nilai Fhitung lebih besar dari $F_{\text {tabel dengan hasil }}$ perbandingan 28,511 $>4,04$ ( $\mathrm{F}$ hitung $>\mathrm{F}$ tabel) dengan nilai signifikan $0,000 \leq 0,05$ sehingga Ho ditolak. Dengan demikian dapat disimpulkan bahwa secara parsial 
variabel karakteristik individu memiliki pengaruh yang signifikan terhadap variabel kemampuan manajerial kepala madrasah.

Analisis korelasi digunakan untuk mengetahui hubungan variabel karakteristik individu dengan variabel kemampuan manajerial kepala madrasah, diperoleh hasil analisis sebagai berikut:

\begin{tabular}{|l|l|l|}
\hline Model & $\mathbf{R}$ & R square \\
\hline 1 & 0,610 & 0,373 \\
\hline
\end{tabular}

Berdasarkan output tersebut dapat diketahui koefisien korelasi (R) antara variabel karakteristik individu dan variabel kemapuan manajerial kepala madrasah sebesar 0,610 dengan nilai $\mathrm{R}_{\text {tabel }}$ pada tingkat signifikansi $5 \%$ adalah sebesar 0,279 . Jika kedua nilai ini dibandingkan maka nilai $\mathrm{R}$ hitung lebih besar dari $\mathrm{R}$ tabel dengan hasil perbandingan 0,610 >0,279 ( $R_{\text {hitung }}>R_{\text {tabel }}$ ), hal ini menunjukkan terdapat hubungan antara karakteristik individu dengan kemampuan manajerial kepala madrasah. Sedangkan hasil uji signifikansi diperoleh nilai $\mathrm{t}_{\text {hitung }} 5,333$ pada taraf signifikansi 5\%, diperoleh $t$ tabel sebesar 1,678 dengan hasil perbandingan $t$ hitung $(5,333)>t$ tabel $(1,678)$ maka Ho ditolak dan Ha diterima. Dengan demikian dapat disimpulkan bahwa terdapat hubungan yang signifikan antara variabel karakteristik individu terhadap kemampuan manajerial kepala madrasah, dengan nilai koefisien determinasi atau $\mathrm{R}$ Square sebesar 0,373 atau $37,3 \%$. Hal ini menunjukan bahwa variabel yang diteliti karakteristik individu dapat memberikan pengaruh terhadap kemampuan manajerial kepala madrasah sebesar $37,3 \%$, sedangkan sisanya $62,7 \%$ dipengaruhi variabel yang tidak diteliti.
Hasil ini menunjukkan bahwa semakin baik karakteristik individu yang meliputi keahlian, pendidikan dan pengalaman kerja yang dimiliki kepala madrasah, maka kemampuan manajerial kepala madrasah akan semakin baik. Hal ini disebabkan karena kepala madrasah mampu mengaplikasikan tugas-tugas pokok sebagai kepala madrasah yaitu merencanakan, mengelola, memimpin dan mengendalikan program dan komponen penyelenggaraan pendidikan pada madrasah berdasarkan standar nasional pendidikan.

Kemampuan berkomunikasi bagi kepala madrasah merupakan salah satu kunci kesuksesan dalam kepemimpinannya. Kemampuan tersebut meliputi kemampuan menyampaikan konsep tentang kebijakan dan gagasan-gagasan inovatif untuk kemajuan madrasah kepada seluruh warga madrasah. Kepala madrasah juga melakukan pengembangan profesi berkelanjutan untuk menunjang kemampuan individu (keahlian, pendidikan dan pengalaman kerja ) melalui pengembangan pengetahuan, keterampilan, dan sikap serta pengembangan diri sebagai kepala madrasah dengan memanfaatkan kemajuan tekhnologi informasi untuk peningkatan kompetensi sebagai kepala madrasah dengan melakukan publikasi ilmiah dan karya inovatif. Hasil penelitian ini selaras dengan penelitian Siswantoro (2009) yang menyatakan bahwa pengembangan karir dapat dibangun dari karakteristik individu yaitu keahlian, pendidikan, dan pengalaman.

\section{Pengujian hipotesis secara parsial: Pengaruh karakteristik organisasi terhadap kemampuan manajerial kepala madrasah}


Pengaruh karakteristik organisasi terhadap kemampuan manajerial kepala madrasah secara parsial dapat dilihat dengan menggunakan analisis regresi linier sederhana dengan persamaan sebagai berikut: Kemampuan manajerial $(\hat{Y})=\beta_{0}+\beta_{1} X_{2}+e$ hasil pengolahan analisis regresi sederhana sebagai berikut: Kemampuan manajerial $(\hat{Y})$ $=1,456+0,598 \mathrm{X} 2+\mathrm{e}$. dari persamaan regresi linier sederhana di atas diperoleh nilai konstanta sebesar 1,456 artinya apabila nilai karakteristik organisasi bernilai nol maka akan memberikan nilai kemampuan manajerial kepala madrasah sebesar 1,456.

Uji linearitas adalah pengujian yang bertujuan untuk mengetahui apakah regresi bersifat linier atau tidak. Uji linieritas dalam penelitian ini menggunakan tabel ANOVA variabel $X$ dan $Y$ dari nilai signifikan. Apabila nilai signifikan tabel ANOVA $<0,05$ maka dapat disimpulkan bahwa hubungan bersifat linier dengan hasil sebagai berikut:

\begin{tabular}{|ll|l|l|l|}
\hline \multicolumn{2}{|l|}{ Model } & Df & F & Sig \\
\cline { 1 - 3 } 1 & Regresi & 1 & 75,755 & 0,000 \\
\cline { 1 - 2 } Residual & 48 & & \\
\cline { 1 - 2 } Total & 49 & & \\
\hline
\end{tabular}

Berdasarkan tabel dapat dilihat bahwa nilai signifikan tabel ANOVA sebesar 0,000 artinya nilai signifikan kurang dari 0,05 $(0,000<0,05)$ yang berarti bahwa hubungan bersifat linier. Hal ini menunjukan bahwa karakteristik organisasi berpola linier terhadap kemampuan manajerial kepala madrasah. Sedangkan untuk mengetahui signifikan pengaruh variabel karakteristik organisasi secara parsial terhadap kemampuan manajerial kepala madrasah digunakan uji F. Diperoleh nilai $\mathrm{F}$ hitung sebesar 75,755.pada nilai $\mathrm{F}$ tabel pada tingkat signifikansi 5\% adalah sebesar 4,04. Jika kedua nilai ini dibandingkan maka nilai $\mathrm{F}$ hitung lebih besar dari $F$ tabel dengan hasil perbandingan 75,755 $>4,04(\mathrm{~F}$ hitung $>\mathrm{F}$ tabel $)$ dengan nilai signifikan $0,000 \leq 0,05$ sehingga Ho ditolak. Dengan demikian dapat disimpulkan bahwa secara parsial variabe karakteristik organisasi memiliki pengaruh yang signifikan terhadap variabel kemampuan manajerial kepala madrasah.

Analisis korelasi digunakan untuk mengetahui hubungan variabel karakteristik organisasi dengan variabel kemampuan manajerial kepala madrasah. Berdasarkan output tersebut dapat diketahui koefisien korelasi (R) antara variabel karakteristik organisasi dan variabel kemapuan manajerial kepala madrasah sebesar 0,782 dengan nilai $\mathrm{R}$ tabel pada tingkat signifikansi 5\% adalah sebesar 0,279. Jika kedua nilai ini dibandingkan maka nilai $\mathrm{R}$ hitung lebih besar dari $\mathrm{R}_{\text {tabel }}$ dengan hasil perbandingan 0,782 > 0,279 ( $R_{\text {hitung }}>R_{\text {tabel }}$ hal ini menunjukkan terdapat hubungan antara karakteristik organisasi dengan kemampuan manajerial kepala madrasah. Sedangkan hasil uji signifikansi diperoleh nilai $\mathrm{t}$ hitung sebesar 8,693 pada taraf signifikansi $5 \%$, diperoleh $\mathrm{t}$ 
tabel sebesar 1,678 dengan hasil perbandingan $\mathrm{t}_{\text {hitung }}(8,693)>\mathrm{t}_{\text {tabel }}(1,678)$ maka Ho ditolak dan $\mathrm{Ha}$ diterima. Dengan demikian dapat disimpulkan bahwa terdapat hubungan yang signifikan antara variabel karakteristik organisasi terhadap kemampuan manajerial kepala madrasah dengan nilai koefisien determinasi atau R Square sebesar 0,612 atau $61,2 \%$. Hal ini menunjukan bahwa variabel yang diteliti karakteristik organisasi dapat memberikan pengaruh terhadap kemampuan manajerial kepala madrasah sebesar $61,2 \%$, sedangkan sisanya $38,8 \%$ dipengaruhi variabel yang tidak diteliti.

Hasil ini mengindikasikan bahwa karakteristik organisasi yang meliputi sumber daya organisasi, iklim organisasi dan struktur organisasi serta didukung oleh anggaran yang cukup, kepala madrasah mampu mengelola dan membuat perencanaan dengan baik, kemampuan kepala madrasah dalam menyampaikan informasi dan organisasi mampu memfasilitasi kemampuan manajerial kepala madrasah menyebabkan meningkatnya kemampuan manajerial kepala madrasah tsanawiyah negeri se Kota Mataram. Hasil penelitian ini selaras dengan penelitian Handayani (2010) yang menyatakan bahwa karakteristik organisasi yang meliputi sumber daya organisasi, iklim organisasi, struktur organisasi berpengaruh signifikan secara parsial terhadap pengembangan karir PNS pejabat struktural pada kantor pemerintah provinsi NTB

Dengan demikian variabel karakteristik organisasi merupakan faktor yang sangat baik aplikasinya dalam mempengaruhi kemampuan manajerial kepala madrasah tsanawiyah negeri se Kota Mataram, namun bukan berarti faktor yang lain diabaikan tetapi dalam praktek sehari-hari nampak bahwa karakteristik individu yang meliputi keahlian, pendidikan dan pengalaman kerja lebih bermakna ketimbang variabel yang lain. Hal ini disebabkan faktor-faktor tersebut dalam praktek di lapangan lebih diperhatikan oleh setiap kepala madrasah dalam meningkatkan kemampuan manajerial

\section{PENUTUP}

\section{Simpulan}

Berdasarkan hasil analisis data dan pembahasan, maka dapat disimpulkan sebagai berikut : 1. Karakteristik individu dan karakteristik organisasi berpengaruh terhadap kemampuan manajerial kepala madrasah tsanawiyah negeri se Kota Mataram. 2. Karakteristik individu berpengaruh terhadap kemampuan manajerial kepala madrasah tsanawiyah negeri se Kota Mataram. 3. Karakteristik organisasi berpengaruh terhadap kemampuan manajerial kepala madrasah tsanawiyah negeri se Kota Mataram.

\section{Saran}

Peneliti selanjutnya perlu menambah jumlah sampel yang digunakan karena jumlah populasi yang lebih besar maka jumlah guru dan pegwai yang akan digunakan menjadi sampel lebih banyak, selain itu variabel independen dalam penelitian ini hanya mampu mempengaruhi variabel dependen sebesar 79,6\%, oleh karena itu perlu adanya penambahan variabel penelitian untuk memprediksi kemampuan manajerial. Untuk penelitian selanjutnya sebaiknya perlu menambah jumlah variabel yang digunakan untuk 
memprediksi kemampuan manajerial kepala madrasah misalnya menambah variabel kualitas kerja dan prestasi kerja guru dan pegawai .

\section{DAFTAR PUSTAKA}

Arikunto, S.2013. Prosedur Penelitian, Satu Pendek, atan Praktek. Jakarta: Rineka Cipta.

Handayani, D. 2010. Pengaruh Karakteristik Individu, Karakteristik Organisasi, Penempatan Pegawai Terhadap Pengembangan Karir Pegawai Pejabat Structural Pada Kantor Pemerintah Propinsi Nusa Tenggara Barat. Tesis Magister FE UNRAM Mataram: tidak diterbitkan.

Hasibuan, M.E. 2000. Manajemen Sumber Daya Manusia. Jakarta: Bumi Aksara

Kurniadin, D. \& Machali, I. 2012. Manajemen Pendidikan, Konsep dan Prinsip Pengelola Pendidikan. Jogyakarta: Ar-Ruz media.

Marno \& Supriatno, T. 2013. Manajemen Kepemimpinan Pendidikan Islam. Bandung : PT. Rafika Aditama.

Robbins, S.P. 2002. Prinsip-prinsip Prilaku Organisasi. Edisi ke-5 (Edisi Bahasa Indonesia). Jakarta: Erlangga

Simamora, H. 1997. Manajemen Sumber Daya Manusia. Cetakan ke-1, Yogyakarta: STIE YKPN.

Sudjarwo \& Basrowi, 2009. Manajemen Penelitian Sosial. Bandung : Mandar Maju

Said, M. 2010. Kepemimpinan, Pengembangan Organisasi. Malang: UIN-Maliki Press.

Siswantoro, T.A. 2009. Analisis Pengaruh Karakteristik Individu dan Karakteristik
Organisasi Terhadap Pengembangan Karir Pegawai (Studi Kasus pada Kantor Badan Pengawas Pasar Modal dan Lembaga Keuangan Departemen Keuangan). Pusat Dokumentasi dan Informasi Ilmiah UNS (online), 2009 Tersedia http://eprints.uns.ac.id/id/eprint/8947/ (5 Januari 2015)

Thoha, M. 1993. Prilaku, Organisasi; Konsep Dasar dan Aplikasinya. Jakarta: PT Raja Grafindo Persada 